\title{
Connection of Tolerance and Bilingualism
}

\author{
Aliya Nasyrova
}

Candidate of Pedagogical Sciences, Head of the Department, Karaganda State Medical University, Karaganda, Kazakhstan Email: alya9300@mail.ru

\author{
Altyn Muratova \\ Senior Lecturer, Karaganda State Medical University, Karaganda, Kazakhstan \\ Email: altynmuratova@mail.ru
}

Saule Shakhina

Candidate of Philological Sciences, Associate Professor, Karaganda State Medical University, Karaganda, Kazakhstan Email: altynmuratova@mail.ru

\section{Berik Rakhimov}

Doctor of Philological Sciences, Professor, Karaganda State Medical University, Karaganda, Kazakhstan Email: altynmuratova@mail.ru

\section{Doi:10.5901/mjss.2015.v6n2s4p115}

\section{Abstract}

The specificity of coexistence of the language units of two different languages in the speech fiber of the expressions and texts has been analyzed. The notion 'two-dominance' has been considered as the basis of intercultural dialogue and a condition of the communicative tolerance. There has been distinguished the units of the Kazakh language of different degree of acquisition which enter into the Russian language. The authors analyzed the nature of intercalation and inclusion and their types. They defined the place of cultural bilingualism in the society.

Keywords: bilingualism, inclusion, intercalation, intercultural dialogue, language units

\section{Introduction}

The interest to tolerance appeared in the society long time ago. There are different determinations of this notion. In the Russian linguistics it is considered in different aspects: the linguo-cultural field of tolerance is described, and the specificity of tolerance and indulgence representation in the Russian picture of the world is detected, and the differences between tolerance and indulgence are established (L.P. Krysin, O.A. Mikhailova, I.A. Sternin, D.A. Shmelev and etc.). For the Kazakh language consciousness the difference between notions "tolerance" and "indulgence" is almost absent. The word tezimdilik (төзімділік) - "shydamdylyk, kөnbistik" ("шыдамдылық, көнбістік") ("tolerance, steadfastness") determines tolerant relation to other/foreign approved by Kazakh people and peculiar to it. Adoption of these foreign subjects is typical generally for the mentality of Kazakh people. The notion of "tolerance" by many Kazakhstan philosophers is connected with the ideas of Eurasianism (S.A. Akatai, T.K. Burbaev, M. Nysanbaev and etc.). They mark the original basic values, developed in the steppe: tolerance, tenderness, trustfulness, openness, generosity, priority of spiritual over material, and compromise nature. Namely these values allow regulation of the intracultural and intercultural public relations on the basis of mutual understanding. Today tolerance as a category that regulates first of all interpersonal relations is perceived as a security of the successful international interaction.

In application to Kazakhstan the intercultural and interlanguage tolerance acquires the special importance both on the state and routine level. In the multinational state, which Kazakhstan is, the language is necessary that would be a means of communication for all people, who leave on one territory. Today this language is the Russian one. The Russian language on the routine level serves all layers of the society, independently on the age, sex, social and ethnic belonging. The state policy is directed on the support of both Kazakh and Russian languages. The state suppression of one 
language over the other one is absent. This promotes to preservation of stability in the society and formation of the tolerant intercultural dialogue.

\section{Materials and Methods}

We would like to consider the specificity of coexistence of the language units of two different languages in the speech fiber of the expressions and texts. As it is known, the living language environment is the dominating factor at language acquisition.

Namely in the childish age the language is mastered successfully, and the high degree of tolerance of speech communication is fixed. Having communicated in different languages, they can show understanding and ability to use different language forms.

Interlanguage contacts of Kazakh children in the spontaneous environment are not troubled and evidence about natural character of the communicative tolerance, as for example, in the dialogue of girls, which study in the different schools (with Kazakh language of study and with the Russian language of teaching):

Asel: Сауле, выйдешь на улицу? (Saule, will go outside?)

Saule: Жоқ, Асель, шыға алмаймын. Үйді жинау керек (No, I can't. I must tidy up the house).

Asel: Yŭdi тез жина да, далаға шық. (Clean the house and go outside). I will show you the new game. I have downloaded it recently.

Saule: Жарайды, шығамын (Ok, I will go out). What kind of the game it is?

In application to the age group of adults it is possible to speak about different degrees of tolerance. The communicants enter into intercourse pursuing the solution of certain communicative tasks, which have the necessary background knowledge, which are realized in the process of intercultural contacts. The achievement of the full mutual understanding in this case is possible at observance of the norms of intercultural dialogue. In the speech communication of representatives of the different ethnic groups the choice of communicative language is especially peculiar. The aspiration of the Russian ones to communication in Kazakh and inclusion of the Kazakh words in their speech is observed recently.

\section{Discussion}

The communicative tolerance and bilingualism is inseparably linked with each other. This connection and its concrete displays can be detected in the speech fiber of dialogues - intracultural and intercultural. This connection displays itself especially brightly in the area of aesthetic set communication.

Tolerance, understood as acceptance of the other one, is the aspect of each text category. Penetrating into all text forming categories, it determines the author's position, determines thematic filling of the text, forms connection between them, and stimulates selection and direction of interpretation of the precedent signs of both cultures. The categorical properties of the bilingual text provide display of the mechanism of tolerant interaction and promotes to formation of the culture dialogue. Thus, the tolerance can be considered as a peculiar linguo-cultural result of realization of the categorical mechanisms of a text. At domination of the Russian language as a means of creation of the bilingual text is observed as cultural-outlook Kazakh dominant. Two-dominance is the basis of intercultural dialogue as a condition of the communicative tolerance.

The lexical units of Kazakh language enter into speech of the Russian people not periodically, but constantly and gradually fixing in it. Presently such units as "Nauryz", "shanyrak", "dastarkhan", "akyn", "tenge", "akim", "mazhilis", "baursak" («Наурыз», «шанырак», «дастархан», «акын», «тенге», «аким», «мажилис», «баурсак») and others are not perceived in the Russian language of Kazakhstan, as they don't require translation or explanation, as they are distributed and assimilated enough well, similar as in the Russian language in Russia such Turkic borrowings as "chest", "shoe", "pencil" and others don't require translation. These inclusions, in connection with their comparatively small quantity in relation to the basic mass of lexical units of the Russian language, can't effect on the integrity of the lexical systems, but show their regional attribution and originality. The correction of ethnic groups' features takes place under the effect of the language and environment (Baideldinov, 2002).

The units of Kazakh language of different degree of acquisition enter into the Russian language, both nonequivalent and equivalent. Such words can be distributed into the following groups - these are lexical units, connected:

1) with festives (наурыз, той, курбан айт) 
2) with customs and rites (тусау кесу, аластау, шильдехана, бет ашар),

3) with national dishes (курт, айран, кумыс, коже)

4) with national cloths (саукеле, кимешек, камзол)

5) with national games (алтьыбакан, асык, тогызкумалак)

6) with religion (намаз, коран, суре)

7) with other subjects (щанырак, тундик, туырлык)

8) with music (домбра, кюй, айтыс, акын)

9) with policy (аким, мажилис, маслихат)

10) with relative relations (женге, ата, баур)

11) with animals (тулпар, бура, атан)

12) with plants (саксаул, жусан, адыраспан)

First of all, the issue about status of lexical unit data appears. In the article "Some tendencies of Kazakh language effect on the Russian language in Kazakhstan" by N.N. Chaikovskaya, L.P. Osenmuk the borrowed units are named Kazakh words (Chaikovskaya \& Osenmuk). E.A. Zhuravleva (2009) in the article "The Problem of national variability of the languages: peculiarities of the Russian language development in Kazakhstan" name the lexical units of Kazakh language as the regional units. In our view, the term "Kazakh words" more exactly express the essence of lexical units of similar type.

In our understanding, the Kazakh words have the status of Kazakh units in a bilingual text, which are not fixed in the explanatory dictionaries of the Russian language, and are not assimilated by the Russian language. The increased attention to the word as a typical feature of the bilingual individuals was stated by L.V. Shcherba yet: "the contact of one language with other ones on the background of comparisons, - as one and the same thought in the different languages is expressed differently, - in a natural way stops on the means of expression and makes a human be attentive to the thin nuances of thought and feeling. This makes it naturally, more receptive to the analysis and perception of the words, expressed or read" (Shcherba, 1957).

The speech behaviour of a bilingual person is the choice of one or other language at communication, as well as the coded switching, which is understood as the change of one language by the other ones by the participants of communication within the limits of one communicative act. The comparative analysis of the speech behaviour of bilingual persons supposes detection and description of the elements of second language (morphemes, lexical units, wordexpression, sentences), called inclusions, which are included into the texts, written in one language.

In the bilingual person consciousness two languages are coincided and it is natural for him to use the language units of two languages that can even lead to mixing the languages.

The Kazakh scientist A.E. Karlinskii distinguishes 2 types of speech displays of the language contacts: interference (effect of the initial language on the second one) and intercalation - effect of the second language on the first one. Effect touching the very system of language is qualified as transference and transcalation. The interference and intercalation represents speech mutation, transference and transcalation - the consequence of speech interaction - language diffusion.

First of all, we are interested in the phenomenon of interaction of language units in speech, which following after Karlinskii A.E., we also call intercalation.

A.E. Karlinskii considers two signs to be important ones in the classification of intercalation types: wedging-in of the words and units, which are bigger than a word - word-combination; change or conservation of the characteristics of the source language, i.e. presence or absence of interference effect on the units L2 (Karlinskii, 1978: 115-116). According to these signs he distinguishes four types:

1. Inventory intercalation - inclusion of separate words of L2 in the speech in L1: Может, бүгін кешке киноға барсақ қайтеді, егер свободный болсаң - Perhaps, today in the evening we'll go to the cinema, if you are free.

2. Phrase intercalation - wedging-in of syntagmas into speech in $\mathrm{L} 1$ - from word-combination to the sentence: $A$ у вас колбаса бар ма? - Do you have a sausage?

3. Pure intercalation - inclusion of L2 units, not subjected to the interference effect of L1 (all above-stated examples).

4. Modified intercalation - inclusion of L2 units, subjected to interference effect. For example: - Сәлем! Қалың қалай? - How do you do? How are you? - ... - And you? Thus, in intercalation qualification the attention is paid to the degree of intervention of the second language elements and on the purity of reproduction of $L 2$ units. Based upon this, it is possible to judge about significance of $L 2$ for a bilingual person.

Presently, the effect of Kazakh culture and role of Kazakh language are extremely significant in the spiritual and 
public life of the Russian language speakers. Except for common Turkic words, such forms of address entered into the constant speech usage of the Russian man as ana (form of address to a woman, elder by age; speech etiquette lexical units: салем (hello), салеметсізбе (how do you do!), рахмеm (thank you), буйырca (God willing), enmen-cenmen (soso!). There are a lot of onomastic units, hydronyms (Semei, Arys), toponyms (Taraz, Shymkent) and mainly anthroponyms (Kurmangazy, Abai, Bukhar-zhyrau). The lexical and phraseological inclusions relate first of all to the area of linguo-cultural nomination. Intercalated lexical units in the Russian language are subjected by the corresponding wordformation adaptation, i.e. begin to develop the certain word-formation ranks: from words ana, әже (grandmother), ama (grandfather), балдыз (sister-in-law) with the help of suffix -к, -шк, апашка, әжека, балдызка are formed; кумысолечение, кумысный from the word koumiss (mare milk), муфртияm from the word mufti with the help of suffix am is formed, the adjective арычный is formed from the word арык, the verb побешбармачить is formed from the word бешбармак. The word аким forms the whole word-formation range: аким - акимат - акиматчик - акиматовский. Also for comparison: adaeu, адаевец, бишарашка, женгешка.

Together with this, we can observe that Kazakh borrowings are subjected to the morphological adaptation қатық (national drink from the sour milk), шужық (horse sausage), тенге (monetary unit), тиын (coin that corresponds to a kopeck). For comparison: с какой-то шильдеханы, ходили на узату; налажено производство молочных продуктов: кумыса, катька, айрана (from some shildekhan, went to wedding; the milk product manufacture is adjusted: koumiss, katyk, ayran).

"Without receiving a tyiyn from the state, we ourselves with own efforts only in the last year attracted investments for the amount more than 30 millions of tenge".

In the texts of newspaper publications the inventory intercalations are widely used, which determine Kazakh routine nationally-biased lexicon or cultural notions, which as a rule are not translated: Суюнши - всегда хорошие новости! (Suyunshi - always good news!).

Among Kazakh inventory intercalation the nominative units are widely distributed, for example: байбише, тоқал, суюнши, чапан, талкан (oat flour), тары, айран (sour milk drink), сыбызды (reed-pipe), кюй (melody for musical instrument), тұндық (upper wooden circle of the nomad's tent framework) that is connected with a dialogue of the Russian and Kazakh cultures.

The most widely distributed stable expressions and phraseological units are among binary inclusions. For comparison, "The rite of neke kiyu was conducted, and Nurzhan's mother and brother were witnesses". "The militia lieutenant Nurlan Omarov, who took deliveries in his wife during the trip into maternity hospital, celebrated besik toi of his son".

Such binary inclusions are most frequently used for designation of the phenomena and ritual notions specific for the Kazakh daily life. Using of such type stable word-combinations and expressions is explained by that the choice of Kazakh lexical units is connected with effect of the Kazakh culture on the specificity of life, outlook and behaviour of the Russian speaking journalists.

Sometimes it is possible to meet phenomena of the phrasal intercalation in the publicist materials, i.e. inclusions of the single-formed segments in one language into the text in the other language. "Each Kazakh must know his ancestors and his жеті ата. If he didn't know that, the old men scornfully told: «Жеті атасын білмеген, жетесіз». (That one who doesn't know seven generation of the ancestors is a soulless person).

\section{Conclusion}

The aspiration to the maximally possible cultural bilinguism that is more accessible for the Kazakh people today, but not to the Russian ones, must become the security of the harmonious existence of modern Kazakhstan society. This is confirmed by the results of sociological inquiries stated in the book of A. Malaeva "Over-ethnic identity of Kazakh and Russian people in Kazakhstan". The author makes conclusion that the Kazakh people are endowed with tolerance in greater extent than the Russian ones and are ready to interact with the representatives of this ethnic group on all levels (Malaeva, 2000).

Presently the Kazakh people completely professionally use the Russian language, as for them it continues to the language of the scientific and professional activity. L.A. Baideldinov emphasizes the phenomena of the cultural ambivalence of the title nation. "A soul of ethnic elite representatives of the Kazakh people, as we can think, is ambivalent in certain extent: from the one part, it is connected with culture and life of the Kazakh people by the deep emotional roots, but from the other part, the world and its cultural values in greater extent were disclosed and mastered by the representative of Kazakh ethnic elite owing to attraction to the Russian culture and language" (Shcherba, 1957).

The lexical units of Kazakh language enters into speech of the Russian people not periodically, but constantly and 
gradually fixing in it. Presently such units as "Nauryz", "shanyrak", "dastarkhan", "akyn", "tenge", "akim", "mazhilis", "baursak" («Наурыз», «шанырак», «дастархан», «акын», «тенге», «аким», «мажилис», «баурсак») and others are not perceived in the Russian language of Kazakhstan, as they don't require translation or explanation, as they are distributed and assimilated enough well, as well as in the Russian language in Russia such Turkic borrowings as "chest", "shoe", "pencil" and others don't require translation. These inclusions, in connection with their comparatively small quantity in relation to the basic mass of lexical units of the Russian language, can't effect on the integrity of the lexical systems, but show their regional attribution and originality. The correction of ethnic groups' features takes place under the effect of the language and environment.

\section{References}

Chaikovskaya, N.N. \& Osenmuk, L.P. Some tendencies of the Kazakh language effect on the Russian language in Kazakhstan. Retrieved from: http://inlang.linguanet.ru/ScientificWork/ScientificArticles/detail.php?ELEMENT_ID=2493

Zhuravleva, E.A. (2009). Problem of the national language varieties: peculiarities of Russian language development in Kazakhstan. Postsoviet space. Eurasian idea in XXI century: new vector of development. EuroAsia, 4, 69-79.

Shcherba, L.V. (1957). Selected works on the Russian language. Moscow: Nauka.

Karlinskii, A.E. (1978). Two types of language interaction displays. In Psychological and linguistic aspects of the problem of language contacts. Kalinin: Publ.-house of Kalinin. State University, 111-119.

Malaeva, A. (2000). Over-ethnic identity of Kazakh and Russian people in Kazakhstan. Alma-Ata: KAZGOSINTI.

Baideldinov, L.A. (2002). Ethnic linguistic situation in Kazakhstan (to $4^{\text {th }}$ anniversary of adoption of the law "On Languages in the Republic of Kazakhstan"). Retrieved from: http://www.kisi.kz/site.html?id=682 
